\title{
Neurological complications of COVID-19: from bridesmaid to bride
}

\author{
Complicações neurológicas do COVID-19: de dama de honra à noiva \\ Avindra NATH' Bryan SMITH ${ }^{1}$
}

\author{
${ }^{1}$ National Institutes of Health, \\ National Institute of Neurological \\ Disorders and Stroke, Section of \\ Infections of the Nervous System, \\ Bethesda, Maryland, USA. \\ Avindra NATH (D) https://orcid. \\ org/0000-0003-0927-5855; \\ Bryan SMITH (iD https://orcid. \\ org/0000-0001-9850-5944 \\ Correspondence: Avindra Nath; \\ E-mail:natha@ninds.nih.gov \\ Conflict of interest: There is no \\ conflict of interest to declare. \\ Received on July 23, 2020 \\ Received in its final form on \\ July 23, 2020 \\ Accepted on July 24, 2020
}

\section{(c) BY}

A $\mathrm{s}$ we write this editorial, we ask ourselves, why is the description of neurological complications of SARS-CoV-2 newsworthy? The virus causes multiorgan involvement, so the brain would surely be affected, just like other parts of the body. Yet it comes as a surprise to many that so many neurologic issues arise in these patients, and that the complications seen are often severe ones. The SARS-CoV-2 virus is a respiratory pathogen and hence complications affecting the brain could be secondary to hypoxia and metabolic derangements. However, the current paper by Studart-Neto et al..$^{1}$ finds, and other similar descriptions emerging from around the world show that the vast majority of patients have other types of neurological involvement, some of which can be severe $e^{2,34,5}$. While loss of smell and taste is the most common symptom observed, nearly half of the patients hospitalized have some form of encephalopathy and about a fifth of the patients develop strokes ${ }^{6,7}$.

The current paper provides the most detailed description of the various neurological manifestations in this population. The authors show that even in the acute phase, neurological complications can involve the entire neuraxis, which includes peripheral neuropathies and rhabdomyolysis (Table 1) . $^{8}$ The number of neurological complications of SARS-CoV-2 is steadily increasing in their hospital on a daily basis, clearly an ominous sign. These complications are being recognized in the acute phase of the illness. However, there are additional postviral syndromes affecting the nervous system, including dysautonomia ${ }^{9}$ and persistent fatigue, exercise intolerance, and malaise that many patients are experiencing months after recovering from the acute illness (Table 1) ) $^{10,11,12,13,14}$. Many of these patients had only minimal respiratory symptoms. The long-term consequences of these manifestations can have a major impact on all aspects of health care, with major socioeconomic consequences. Hence, the neurological manifestations should be front and center to the disease.

Brazil has faced many major epidemics in the recent past, which include Zika, Dengue, Chikungunya, and now SARS-CoV-2. Each of these pathogens causes neurological complications. The country was the first to alert the world about the devastating fetal complications of Zika virus and has led the field in studying the epidemiology, clinical manifestations, and pathophysiology of these diseases. But today we all face the biggest challenge of all times. SARS-CoV-2 has brought the entire healthcare system worldwide to its knees. A respiratory pathogen that can cause neurological complications is our biggest nightmare. Combined with the rapidity of spread of this virus and its ability to mutate to alter its pathogenicity has evaded the best of minds

Table 1. Neurological manifestations of COVID-19 caused by SARS-CoV-2.

\begin{tabular}{ll}
\multicolumn{1}{c}{ Acute } & \multicolumn{1}{c}{ Post-viral } \\
\hline - Anosmia & - Acute disseminated encephalomyelitis \\
- Myalgia/myositis & - Acute necrotizing hemorrhagic encephalopathy \\
- Encephalopathy & - Transverse myelitis \\
- Stroke & - Guillain-Barré syndrome \\
- Meningitis/encephalitis & - Multisystem inflammatory syndrome (Kawasaki's disease) \\
- Seizures & - Myalgic encephalomyelitis/chronic fatigue syndrome \\
- Peripheral neuropathy & - Dysautonomia \\
- Rhabdomyolysis &
\end{tabular}


and challenged all scientific advancements. Today, we have the ability to treat the rarest form of genetic illnesses, but we no have effective treatment in sight for the smallest of organisms that has spread to every corner of the planet. We have treated thousands of patients with hydroxychloroquine to the point where there is a worldwide shortage of the drug without much scientific basis for such treatment. This desperate attempt to treat with anything, despite a lack of science, shows the power this virus has on the world's population.

In multiple visits to Brazil, it has become clear that Brazilians have impressive resilience and tremendous depth of knowledge, warmth, and compassion. Brazil will overcome this crisis and emerge stronger than ever. They have a bright future.

\section{References}

1. Studart-Neto A, Guedes BF, De Luca E Tuma R, Camelo Filho AE, Kubota GT, lepsen BD, et al. Neurological consultations and diagnoses in a large, dedicated COVID-19 university hospital. Arq Neuro-Psiquiatr. 2020 Jul. [Epub ahead of print]. https://doi. org/10.1590/0004-282X20200089

2. Filatov A, Sharma P, Hindi F, Espinosa PS. Neurological complications of coronavirus disease (COVID-19): encephalopathy. Cureus. 2020 Mar;12(3):e7352. https://doi.org/7310.7759/cureus.7352

3. Mao L, Jin H, Wang M, Hu Y, Chen S, He Q, et al. Neurologic manifestations of hospitalized patients with coronavirus disease 2019 in Wuhan, China. JAMA Neurol. 2020 Apr;77(6):1-9. https://doi. org/10.1001/jamaneurol.2020.1127

4. Moriguchi T, Harii N, Goto J, Harada D, Sugawara H, Takamino J, et al. A first case of meningitis/encephalitis associated with SARSCoronavirus-2. I Int J Infect Dis. 2020 May;94:55-8. https://doi. org/10.1016/j.ijid.2020.03.062

5. Tsai LK, Hsieh ST, Chang YC. Neurological manifestations in severe acute respiratory syndrome. Acta Neurol Taiwan. 2005 Sep;14(3):113-9.

6. Li Y, Li M, Wang M, Zhou Y, Chang J, et al. Acute cerebrovascular disease following COVID-19: a single center, retrospective, observational study. Stroke Vasc Neurol. 2020:svn-2020-000431. https://doi.org/10.1136/svn-2020-000431

7. Oxley TJ, Mocco J, Majidi S, Kellner CP, Shoirah H, Singh P, et al. LargeVessel stroke as a presenting feature of Covid-19 in the young. N Engl J Med. 2020 May;382(20):e60. https://doi.org/10.1056/NEJMc2009787
8. Jin M, Tong Q. Rhabdomyolysis as potential late complication associated with COVID-19. Emerg Infect Dis. 2020 Jul;26(7):1618-20. https://doi.org/10.3201/eid2607.200445

9. Kochi AN, Tagliari AP, Forleo GB, Fassini GM, Tondo C. Cardiac and arrhythmic complications in patients with COVID-19. J Cardiovasc Electrophysiol. 2020 May;31(5):1003-8. https://doi.org/10.1111/ jce.14479

10. Poyiadji N, Shahin G, Noujaim D, Stone M, Patel S, Griffith B. COVID19-associated acute hemorrhagic necrotizing encephalopathy: CT and MRI features. Radiology. 2020 Aug;296(2):E119-20. https://doi. org/10.1148/radiol.2020201187

11. Toscano G, Palmerini F, Ravaglia S, Ruiz L, Invernizzi P, Cuzzoni $M G$, et al. Guillain-Barré syndrome associated with SARS-CoV-2. N Engl J Med. 2020 Jun;382(26):2574-6. https://doi.org/10.1056/ NEJMc2009191

12. Zhang T, Rodricks MB, Hirsh E. COVID-19-associated acute disseminated encephalomyelitis: A case report. medRxiv 2020.04.16.20068148. https://doi.org/10.1101/2020.04.16.20068148

13. Zhao H, Shen D, Zhou H, Liu J, Chen S. Guillain-Barré syndrome associated with SARS-CoV-2 infection: causality or coincidence? Lancet Neurol. 2020 May;19(5):383-4. https://doi.org/10.1016/ S1474-4422(20)30109-5

14. Zhou KH, Huang J, Dai D, Feng Y, Liu L, Nie S. Acute myelitis after SARS-CoV-2 infection: a case report. medRxiv. 2020 Apr. https://doi. org/10.1101/2020.03.16.20035105 